\title{
Nkonomics
}

Central European Review of Economics \& Finance

Vol. 26, No. 4 (2018), pp. 37-49

DOI: $10.24136 /$ ceref.2018.020

Received: 29 July 2018. Accepted: 4 September 2018.

Natalia ZAJĄC

\section{THE EVALUATION OF THE SYSTEM OF FINANCING THE INTEGRATION COURSES IN GERMANY}

Persons intending to live in Germany should have a certain knowledge of the German language and about the country in general. Foreigners may acquire the necessary skills and knowledge by participating in integration courses. They are financed by the state as well as by the immigrants themselves. The aim of the article is to evaluate the system of financing such courses that was adopted in Germany. As part of the justification for selecting this particular topic it is worth mentioning that there are no analyses on this subject available in the source literature. Furthermore, also the geopolitical situation in the world and the influx of refugees in Europe (including Germany) that results from it serve to prove just how current and important with regard to cost economics the issue of financing immigrant integration actually is. The analysis has been carried out on the basis of German legal acts and the financial data obtained from the Federal Statistical Office and the Federal Office for Migration and Refugees. The article covers the period January 2017 - July 2018 and is based on the method of document analysis.

Keywords: finances, system, immigrants, Germany, integration course.

JEL Classification Codes: F15, F36.

\section{Introduction}

In the world of globalisation and cultural intermingling the process of integration plays a very important role. Integration is an interdisciplinary term, and as such can be interpreted in different ways. The Dictionary of Polish defines social integration as a process of merging that happens on various social levels (Słownik języka polskiego PWN 2018), whereas in the encyclopaedic sense social integration is a "condition of organisation,

${ }^{1}$ M.Sc., PhD Student, Warsaw University of Life Sciences, Faculty of Economics. 
combination and harmonisation of different elements constituting a social community, pertaining to the sphere of norms and values, actions and unity between individuals and social groups" (Encyklopedia PWN 2018). It is important to be able to integrate with one another for the purpose of socio-economic development despite different historical experiences, cultural diversity, language or legal differences. In the light of the migration from Africa to Europe, which has been gaining force over the last several years, the importance of the integration process has only increased. Europeans start having doubts about "the negative impact the influx of too large numbers of immigrant communities may have on their national identity and general social solidarity, social protection systems or levels of security" (Grzymała-Kazłowska, Łodziński 2008); at the same time it can be observed that immigrant groups separate from the rest of the society for the fear of not being allowed to reconcile their cultural values with the European ones. Social observations confirm that the most effective way towards achieving integration leads through the labour market, so the employers and public bodies play a key role in it. "We cannot speak of integration, if a foreigner is employed illegally or works on the basis of task-specific contracts, performs their duties in inhumane conditions or in isolation" (Mikulska, Patzer 2012). Decent work with fair remuneration constitutes an important integration factor. Unemployment, living in poverty and social exclusion certainly do not facilitate the process. However, providing social support (e.g. accommodation, food, clothes, health insurance), assistance in filling in the documents that confirm the level of education and language skills, or professional activation initiatives require financing. The European Union has also noticed the importance of these aspects. In the process of realising its structural policy, the EU strives towards economic and social cohesion by facilitating the use of resources and increasing competitiveness not only of individual member states, but also of the Union as a whole. Such actions are defined by the priorities of the structural policy, among others priority no. 8 - promoting sustainable and quality employment and supporting labour mobility; priority 9 - promoting social inclusion, combating poverty and any discrimination, and priority 10 - investing in education, training and lifelong learning. (Ministerstwo Rozwoju 2015).

The beginning of the process of the UK leaving the European Union is the reason for uncertainty regarding the future of millions of immigrants living in the British Isles. Those who have been legal residents for at least five years "may apply for a permanent residence permit which will allow them to live and work in the United Kingdom without any restrictions" (Borońska-Hryniewska 2016). However, those who will not qualify for permanent residence could cause another migration wave towards Western Europe (including, for instance, Germany). That is why initiatives aimed at integration have been gaining in importance.

Germany is relatively often chosen by immigrants as the country of permanent residence. It is estimated that the country received 1391515 immigrants in 2017, mainly from countries such as Romania (194 420), Poland (170 460), Bulgaria (83 365), Syria 
(70 650), Italy (65 515) and Croatia (56 265) (Statistisches Bundesamt, 2018a). The scale of this phenomenon and the problems connected to securing financial means for integrating migrants deserve an analysis. Even more so, as in the current economic conditions in Germany - with the country's GDP in 2017 amounting to $€ 3263.35$ billion (Statistisches Bundesamt, 2018b) and the unemployment rate oscillating around 5.7\% (Statistisches Bundesamt, 2018c) - such an evaluation of integration initiatives may be particularly interesting for practical and learning purposes.

The issues described above have until now not been a subject of many analyses. Therefore, this article constitutes an attempt to fill the existing gap in the economic literature. The aim of the article is to evaluate the system of financing the process of integrational support for immigrants in Germany. The analyses have been carried out with the help of the following sources of data: German legislation and financial data obtained from the Federal Statistical Office and the Federal Office for Migration and Refugees. The analysed period encompasses the timeframe between January 2017-July 2018. The analysis is based on the method of document analysis with a particular emphasis on German source literature.

\section{The scope of the system of financing integration measures in Germany}

Immigrants, in order to function well in the new society, should know the official language of the country in which they are living. The knowledge of history, culture, and above all the law is very important for taking up work, completing administrative errands or, in case of parents, for supporting one's children in their education and development. It is with such situations in mind that the idea of integration courses was developed in Germany in 2005. The following documents constitute the legal basis for this type of an integration offer:

1) $\S 43$ and ff of the Residence, Employment and Integration of Foreigners within the Territory of the Federal Republic of Germany Act (Residence Act) (Gesetz über den Aufenthalt, die Erwerbstätigkeit und die Integration von Ausländern im Bundesgebiet (Aufenthaltsgesetz - AufenthG) vom 25. Februar 2008 (BGBI. I 2017 S. 162));

2) Ordinance on Integration Courses (Verordnung über die Durchführung von Integrationskursen für Ausländer und Spätaussiedler (Integrationskursverordnung IntV) vom 13. Dezember 2004 (BGBI. I 2004 S. 3370)).

3) Regulation on the examination and verification procedures for the final tests of integration courses (Verordnung über die Prüfungs- und Nachweismodalitäten für die Abschlusstests des Integrationskurses (Integrationskurstestverordnung - IntTestV) vom 9. April 2013 (BGBI. I S. 801)). 
The aim of the integration course is to enable the participants to achieve a sufficient knowledge of German (level B1) in accordance with § 43(3) of the Residence, Employment and Integration of Foreigners within the Territory of the Federal Republic of Germany Act and with § 9(1)(1) of the Federal Law on Refugees and Exiles (Gesetz über die Angelegenheiten der Vertriebenen und Flüchtlinge (Bundesvertriebenengesetz - BVFG) vom 10. August 2007 (BGBI. I S. 1902)) as well as to convey knowledge about the values of the democratic state of the Federal Republic of Germany and the principles of the rule of law, equality of rights, tolerance and religious freedom (Integrationskursverordnung 2004). Foreigners should become familiar with the conditions of living in Germany in order to be able to function on their own in all areas of everyday life without the support or intermediation by third parties. The following persons are eligible to participate in the course:

1) foreigners who are permanent residents in the federal territory if they have received a residence permit for employment purposes, for the purpose of subsequent immigration by dependents, on humanitarian grounds or as a long-term resident i.e. having the legal right to attend the course in accordance with § 44(1) of the Residence, Employment and Integration of Foreigners within the Territory of the Federal Republic of Germany Act,

2) exiles, in accordance with $\S 4(1)$ or (2) of the Federal Law on Refugees and Exiles as well as members of their families in accordance with $\S 7(2)(1)$ of the Federal Law on Refugees and Exiles, or persons entitled to attend the course in accordance with $\S$ 9(1)(1) of the Federal Law on Refugees and Exiles i.e. immigrants of German origin who arrived in Germany from Eastern European countries,

3) persons allowed to participate in accordance with $\S 44(4)$ of the Residence, Employment and Integration of Foreigners within the Territory of the Federal Republic of Germany Act i.e. especially the foreigners whose participation obligation expired, but who demonstrate a willingness to attend the course, foreigners who have permission to remain pending the asylum decision and who are expected to be allowed to remain in Germany lawfully and permanently as well as German citizens, if their command of German is insufficient and they have special integration needs,

4) foreigners obliged to attend the course in accordance with $\S 44 a(1)(1)(2)$ or $\S 44 a$ (1) (3) of the Residence, Employment and Integration of Foreigners within the Territory of the Federal Republic of Germany Act i.e. foreigners receiving benefits in accordance with the Second Book of the Social Code or foreigners who have not fulfilled their participation obligations for reasons they are accountable for, or who have not passed the final test;

5) foreigners who have special integration needs and the Foreigners Office obliges them to attend an integration course, as described in $\S 44 a(1)(3)$ of the Residence, Employment and Integration of Foreigners within the Territory of the Federal Republic of Germany Act, 
6) foreigners obliged to attend the course in accordance with $\S 44 a(1)(4)$ of the Residence, Employment and Integration of Foreigners within the Territory of the Federal Republic of Germany Act i.e. persons referred to in $\S 44(4)$ receiving benefits on the basis of the Asylum Seekers' Benefits Act (Verordnung über die Durchführung von Integrationskursen für Ausländer und Spätaussiedler, 2004).

The above-mentioned groups of persons are entitled to a one-time participation in the integration course. The right to attend expires if the entitled person, due to the reasons ascribable to them, does not commence the integration course within a year from the moment of registration with an official course provider or if the participation in the course exceeds the one-year period (Verordnung über die Durchführung von Integrationskursen für Ausländer und Spätaussiedler, 2004).

In accordance with $\S 44(4)$ of the Residence, Employment and Integration of Foreigners within the Territory of the Federal Republic of Germany Act, a foreigner who does not possess or no longer possesses an attendance entitlement may still be allowed to participate in the course provided there are free places available. This provision is also applicable to German citizens if they do not demonstrate a sufficient command of German or have special integration needs, as well as to foreigners who:

1) have a residence permit and who are expected to remain in Germany legally and permanently;

2) have been granted a permit for a tolerated stay in accordance with $\S 60 \mathrm{a}(2)(3)$ of Residence, Employment and Integration of Foreigners within the Territory of the Federal Republic of Germany Act; or

3 ) have a residence permit in accordance with $\S 25(5)$ of Residence, Employment and Integration of Foreigners within the Territory of the Federal Republic of Germany Act (Gesetz über den Aufenthalt, die Erwerbstätigkeit und die Integration von Ausländern im Bundesgebiet, 2008).

Each integration course consists of two parts: language course and orientation course i.e. introduction to social and civic competences. Within the framework of the general integration course the language part encompasses 600 lessons (45 minutes each). The language part covers important topics from everyday life regarding, among others, the following issues:

1) "work and career,

2) basic and further training,

3) bringing up and raising children,

4) shopping/trade/consumption,

5) leisure time and social interaction,

6) health and hygiene/human body,

7) media and media use, and

8) housing". (Bundesamt für Migration und Flüchtlinge, 2018a). 
The above-mentioned topics vary depending on the type of the course. The language part ends with the final exam "German test for immigrants" that consists of a written and oral part. The written exam lasts 100 minutes and serves to verify the listening, reading and writing skills (writing a short letter). The oral exam lasts approximately 15 minutes and consists of a short introduction and a conversation with the examiners on selected topics (Verordnung über die Durchführung von Integrationskursen für Ausländer und Spätaussiedler, 2004).

As part of the general course, the introduction to social and civic competences encompasses 100 hours (Verordnung über die Durchführung von Integrationskursen für Ausländer und Spätaussiedler, 2004). The following issues are discussed in this part of the course:

1) „the German legal system, history and culture,

2) rights and obligations in Germany,

3) ways of co-existing in society, and

4) important values in German society, e.g. freedom of worship, tolerance and equal rights". (Bundesamt für Migration und Flüchtlinge, 2018a).

The orientation part of the course ends with the final test "Life in Germany" that consists of 33 questions. A minimum result of 15 correct answers is required to pass the test (Verordnung über die Durchführung von Integrationskursen für Ausländer und Spätaussiedler, 2004). In order to obtain a skills certificate in accordance with $\S 10(1)(1)$ of the Citizenship Act, it is necessary to answer at least 17 questions correctly (Verordnung über die Durchführung von Integrationskursen für Ausländer und Spätaussiedler, 2004).

Apart from the general courses there are other types of courses available, as presented in Table 1.

Table 1. Description of the special types of integration courses in Germany in 2017 and 2018

\begin{tabular}{|c|l|l|c|}
\hline No. & \multicolumn{1}{|c|}{$\begin{array}{c}\text { Name } \\
\text { of the integration course }\end{array}$} & \multicolumn{1}{|c|}{ Topics covered during the course } & $\begin{array}{c}\text { Hours } \\
\text { of the course }\end{array}$ \\
\hline 1. & $\begin{array}{l}\text { Integration course includ- } \\
\text { ing literacy skills }\end{array}$ & $\begin{array}{l}\text { Topics from the general course + learning how to read } \\
\text { and write in Latin script }\end{array}$ & $1000-1600$ \\
\hline 2. & $\begin{array}{l}\text { Integration course for per- } \\
\text { sons learning a different } \\
\text { alphabet }\end{array}$ & $\begin{array}{l}\text { Topics from the general course + learning the Latin al- } \\
\text { phabet for persons who have learned reading and writ- } \\
\text { ing in a different writing system. }\end{array}$ & 1200 \\
\hline 3. & $\begin{array}{l}\text { Integration course } \\
\text { for women }\end{array}$ & $\begin{array}{l}\text { Topics from the general course + getting to know some } \\
\text { elements of the educational system in Germany (e.g. } \\
\text { the nursery school and/or school of the participants' } \\
\text { children). Furthermore, topics of special interests to } \\
\text { the participants, such as teaching and bringing up chil- } \\
\text { dren or similarities and differences between the life of } \\
\text { women in Germany and in the participants' countries of } \\
\text { origin, are also discussed during the course. }\end{array}$ & 1000 \\
\hline
\end{tabular}




\begin{tabular}{|c|c|c|c|}
\hline No. & $\begin{array}{l}\text { Name } \\
\text { of the integration course }\end{array}$ & Topics covered during the course & $\begin{array}{l}\text { Hours } \\
\text { of the course }\end{array}$ \\
\hline 4. & $\begin{array}{l}\text { Integration course for } \\
\text { parents }\end{array}$ & $\begin{array}{l}\text { Topics from the general course + getting to know the } \\
\text { nursery school or school of the participants' children. } \\
\text { The person conducting the course introduces the par- } \\
\text { ents to their children's teachers and tutors. The partici- } \\
\text { pants learn in a group of parents who have the same } \\
\text { or similar interests and obtain a lot of useful information } \\
\text { on the structure of the German education system and } \\
\text { the possibilities available to them and their children in } \\
\text { Germany. }\end{array}$ & 1000 \\
\hline 5. & $\begin{array}{l}\text { Integration course for } \\
\text { young adults }\end{array}$ & $\begin{array}{l}\text { Topics from the general course + the participants estab- } \\
\text { lish contacts with education institutions and employers } \\
\text { as well as discuss topics such as: } \\
\text { 1. „school and training, } \\
\text { 2. work and career, } \\
\text { 3. family and living together harmoniously, } \\
\text { 4. health and healthcare provision, } \\
\text { 5. culture and leisure” (Bundesamt für Migration und } \\
\text { Flüchtlinge, 2018f). }\end{array}$ & 1000 \\
\hline 6. & Catch-up course & $\begin{array}{l}\text { This course is aimed at persons who have lived in } \\
\text { Germany for a few years but have not had the chance } \\
\text { to learn German and would like to catch up. The par- } \\
\text { ticipants prepare for the linguistic requirements of the } \\
\text { labour market and social life as well as familiarise them- } \\
\text { selves with the most important facts regarding politics, } \\
\text { history, culture and the legal system in Germany. }\end{array}$ & 1000 \\
\hline 7. & Intensive course & $\begin{array}{l}\text { The thematic scope of the general course compressed } \\
\text { to a reduced number of hours. }\end{array}$ & 430 \\
\hline
\end{tabular}

Source: Compiled by the author on the basis of: Bundesamt für Migration und Flüchtlinge, 2018b; Bundesamt für Migration und Flüchtlinge, 2018c; Bundesamt für Migration und Flüchtlinge, 2018d; Bundesamt für Migration und Flüchtlinge, 2018e; Bundesamt für Migration und Flüchtlinge, 2018f; Bundesamt für Migration und Flüchtlinge, 2018g; Bundesamt für Migration und Flüchtlinge, 2018h.

If, despite regular participation in the course and having used up the full limit of hours of they were entitled to, the participant does not pass the B1 German language test, they can apply for a one-time repetition of 300 hours of the course and retake the test again without any additional costs.

All the aspects discussed during the integration courses (not only from the theoretical, linguistic point of view, but also from the practical one) fit in very well with the key elements of the holistic approach of the EU's integration policy i.e. above all:

1) integration on the labour market;

2) education and language command;

3) housing and urban policies in cities;

4) health protection and social assistance (Kicinger 2005). 


\section{Financial implementation of the integration courses}

The German Federal Office for Migration and Refugees repays the costs of organising integration courses for persons entitled to attend them to the individual course providers in accordance with $\S 14$ and ff of the Ordinance on Integration Courses. From 1 June 2016 the rate for a single lesson was set at $€ 3.90$, reduced by $50 \%$ if the participant pays their share i.e. the participation fee. The Office repays the costs after every 100 lessons of the linguistic course and after conducting the entire orientation course (Bundesamt für Migration und Flüchtlinge 2018i). In order to attend the course the participant needs to pay a fee to the Federal Office for Migration and Refugees that amounts to $50 \%$ of the applicable rate according to $\S 20(6)$ of the already quoted Ordinance on Integration Courses. The fee does not have to be paid in total at once. It is possible to pay in instalments, in advance for every 100 lessons.

In accordance with $\S 43(3)(4)$ of the Residence, Employment and Integration of Foreigners within the Territory of the Federal Republic of Germany Act the person who provides for the potential participant of the course is also obliged to pay the fee. This provision serves as a legal basis for waiving the fee for persons who receive unemployment benefits or benefit from social assistance. If paying the fee poses a particular difficulty due to the economic or personal situation of the course participant they can also apply for a fee waiver. The costs of the exam are covered by the Federal Office for Migration and Refugees (Bundesamt für Migration und Flüchtlinge 2018i). If the participant has been granted a waiver for the participation fee, receives an unemployment benefit or benefits from social assistance, they can also apply for a subsidy for travel costs reimbursement. Such a reimbursement is based on the precondition that the distance between the place of residence and the venue of the course is at least $3.0 \mathrm{~km}$. The Federal Office can also support the participation in the course by providing for childcare for the participants' children if there is no other local institution providing childcare and if they are not subject to compulsory education (Verordnung über die Durchführung von Integrationskursen für Ausländer und Spätaussiedler, 2004).

In 2017, 376468 persons were eligible to participate in the course, including 257925 persons obliged to participate, and 118543 persons who could attend on a voluntary basis. In the end 291911 people participated in the integration courses - 193054 (66.1\%) of those obliged by the state and 98857 (33,9\%) voluntary participants (Bundesamt für Migration und Flüchtlinge, Referat Statistik 2018).

The participation structure of the integration courses according to gender is presented in Table 2. 
Table 2. Participants breakdown by gender in 2017

\begin{tabular}{|l|r|r|r|r|r|r|}
\hline \multirow{2}{*}{ Type of course } & \multicolumn{2}{c|}{ Men } & \multicolumn{2}{c|}{ Women } & \multicolumn{2}{c|}{$\begin{array}{c}\text { Total number } \\
\text { of participants }\end{array}$} \\
\hline General integration course & 102713 & $35,2 \%$ & 81317 & $27,9 \%$ & 184030 & $63,0 \%$ \\
\hline Integration course including literacy skills & 45687 & $15,7 \%$ & 31202 & $10,7 \%$ & 76889 & $26,3 \%$ \\
\hline Integration course for parents and for women & 1455 & $0,5 \%$ & 6556 & $2,2 \%$ & 8011 & $2,7 \%$ \\
\hline Catch-up course & 37 & $0,0 \%$ & 22 & $0,0 \%$ & 59 & $0,0 \%$ \\
\hline Intensive course & 281 & $0,1 \%$ & 291 & $0,1 \%$ & 572 & $0,2 \%$ \\
\hline Integration course for young adults & 6258 & $2,1 \%$ & 2749 & $0,9 \%$ & 9007 & $3,1 \%$ \\
\hline $\begin{array}{l}\text { Integration course for persons learning } \\
\text { a different alphabet }\end{array}$ & 7573 & $2,6 \%$ & 4358 & $1,5 \%$ & 11931 & $4,1 \%$ \\
\hline Other integration courses & 876 & $0,3 \%$ & 536 & $0,2 \%$ & 1412 & $0,5 \%$ \\
\hline Total & 164880 & $56,5 \%$ & 127031 & $43,5 \%$ & 291911 & $100,0 \%$ \\
\hline
\end{tabular}

Source: Compiled by the author on the basis of Bundesamt für Migration und Flüchtlinge, Referat Statistik 2018.

The cost of the integration courses for voluntary participants depends on the number of lessons of the chosen course (See: Table 3)

Table 3. The cost of the integration courses for an individual participant

\begin{tabular}{|c|c|c|c|c|c|}
\hline \multirow{2}{*}{ Type of course } & \multicolumn{2}{|c|}{ Number of lessons } & \multirow{2}{*}{$\begin{array}{c}\text { Cost of a single } \\
\text { lesson }\end{array}$} & \multicolumn{2}{|c|}{ Cost of the entire course } \\
\hline & $\min$. & $\max$. & & $\min$. & $\max$. \\
\hline General integration course & \multicolumn{2}{|c|}{700} & \multirow{8}{*}{$1,95 €$} & \multicolumn{2}{|c|}{1365} \\
\hline Integration course including literacy skills & 1000 & 1300 & & $1950 €$ & $2535 €$ \\
\hline $\begin{array}{l}\text { Integration course for persons learning } \\
\text { a different alphabet }\end{array}$ & 900 & 1000 & & $1755 €$ & $1950 €$ \\
\hline Integration course for women & \multicolumn{2}{|c|}{1000} & & \multicolumn{2}{|c|}{$1950 €$} \\
\hline Integration course for parents & \multicolumn{2}{|c|}{1000} & & \multicolumn{2}{|c|}{$1950 €$} \\
\hline Integration course for young adults & \multicolumn{2}{|c|}{1000} & & \multicolumn{2}{|c|}{$1950 €$} \\
\hline Catch-up course & \multicolumn{2}{|c|}{1000} & & \multicolumn{2}{|c|}{$1950 €$} \\
\hline Intensive course & \multicolumn{2}{|c|}{430} & & \multicolumn{2}{|c|}{$838,5 €$} \\
\hline
\end{tabular}

Source: Compiled by the author on the basis of Bundesamt für Migration und Flüchtlinge, Referat Statistik 2018.

The minimal remuneration for an individual teacher employed by the provider of the integration courses amounts to $€ 35$ for a single lesson (Bundesamt für Migration und Flüchtlinge, 2016). The course provider also receives a one-time payment of $€ 30$ for conducting a placement test that verifies the level of German and determines the type and part of course the person should attend. The costs of the final exam are also covered by the Federal Office. For each person examined the Office pays $€ 91.44$ for the linguistic part and $€ 18.65$ for the orientation part (Bundesamt für Migration und Flüchtlinge, 2018i). The cost of conducting the integration course for an individual par- 
ticipant (entitled to a fee waiver) including the final exams varies depending on the profile of the participant (See: Table 4).

Table 4. The cost of the integration course paid by the Federal Office

\begin{tabular}{|c|c|c|c|c|c|c|c|c|}
\hline \multirow{2}{*}{ Type of course } & \multicolumn{2}{|c|}{$\begin{array}{l}\text { Number of } \\
\text { lessons }\end{array}$} & \multicolumn{2}{|c|}{$\begin{array}{c}\text { Teacher's } \\
\text { remuneration (EUR) }\end{array}$} & \multicolumn{2}{|c|}{$\begin{array}{l}\text { Cost of tests } \\
\text { (EUR) }\end{array}$} & \multicolumn{2}{|c|}{$\begin{array}{l}\text { Total cost } \\
\text { of the course including } \\
\text { exams for one } \\
\text { participant (EUR) }\end{array}$} \\
\hline & min. & $\max$. & min. & $\max$. & 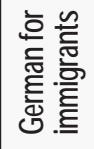 & 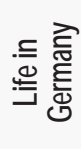 & $\min$. & $\max$. \\
\hline General integration course & \multicolumn{2}{|c|}{700} & \multicolumn{2}{|l|}{24500} & \multirow{8}{*}{91,44} & \multirow{8}{*}{18,65} & \multicolumn{2}{|c|}{24610,09} \\
\hline $\begin{array}{l}\text { Integration course including } \\
\text { literacy skills }\end{array}$ & 1000 & 1300 & 35000 & 45500 & & & 35110,09 & 45610,09 \\
\hline $\begin{array}{l}\text { Integration course for persons } \\
\text { learning a different alphabet }\end{array}$ & 900 & 1000 & 31500 & 35000 & & & 31610,09 & 35110,09 \\
\hline Integration course for women & \multicolumn{2}{|c|}{1000} & \multicolumn{2}{|l|}{35000} & & & \multicolumn{2}{|c|}{35110,09} \\
\hline Integration course for parents & \multicolumn{2}{|c|}{1000} & \multicolumn{2}{|l|}{35000} & & & \multicolumn{2}{|c|}{35110,09} \\
\hline $\begin{array}{l}\text { Integration course for young } \\
\text { adults }\end{array}$ & \multicolumn{2}{|c|}{1000} & \multicolumn{2}{|l|}{35000} & & & \multicolumn{2}{|c|}{35110,09} \\
\hline Catch-up course & \multicolumn{2}{|c|}{1000} & \multicolumn{2}{|l|}{35000} & & & \multicolumn{2}{|c|}{35110,09} \\
\hline Intensive course & \multicolumn{2}{|c|}{430} & \multicolumn{2}{|l|}{15050} & & & \multicolumn{2}{|c|}{15160,09} \\
\hline
\end{tabular}

Source: Compiled by the author on the basis of Bundesamt für Migration und Flüchtlinge, Referat Statistik 2018.

Table 4 presents the minimal cost of the course for one person paid by the Federal Office. However, it has to be taken into account that the calculations are based on the minimal remuneration rate and do not include any additional payments for the teachers e.g. for conducting a special type of course or travel costs subsidies. In 2017 the German state paid $€ 610077000$ for integration courses (Bundesministerium der Finanzen, 2017).

In the long term perspective the immigration on humanitarian grounds may in fact lessen the burden on the public finances in Germany, provided that a successful integration of immigrants into the labour market can be achieved. The stability of public finances improves when immigrants reach the average fiscal capacity of qualified national residents, and the integration process required for it to happen lasts a little longer than 10 years. The failure to integrate immigrants into the qualified labour market may, in a long-term perspective, lead to additional and substantial financial burdens for the citizens. Public spending on effective vocational training and faster economic integration of immigrants could result in a middle- and long-term return in the form of higher revenues from taxes and contributions as well as lower expenses for the basic social 
assistance. Perceived from the perspective of the future returns, today's expenses also serve a fiscal aim - ensuring the stability of public finances in a long-term perspective. (Bonin 2016)

\section{Conclusions}

The analysis of the system of financing integration courses in Germany proves that the Federal Office for Migration and Refugees is the main payer for these courses. This results, among others, from the fact that the majority of the course participants are entitled to a fee waiver due to their difficult economic situation, as social assistance constitutes their only source of income. A complete waiver of the examination fees for all course participants is another burden for the German state. Travel cost subsidies and childcare arrangements are important factors that encourage immigrants to participate in the integration courses. In the light of the growing numbers of immigrants arriving in Germany, a need to increase Federal spending may be expected in order to ensure an effective integration process. Therefore, the policy of the Federal Government in Germany in the future may be directed towards:

1) increasing the participants' share in the costs of the integration process;

2) excluding travel and childcare cost reimbursement from federal financing;

3 ) extending the catalogue of persons obliged to complete integration courses.

\section{References}

Asylgesetz (AsylG), vom 2. September 2008 (BGBI. I S. 1798) as amended.

Bonin H. (2016). Gewinne der Integration Berufliche Qualifikation und Integrationstempo entscheiden über die langfristigen fiskalischen Kosten der Aufnahme Geflüchteter. böll.brief \#1 Teilhabegesellschaft. Heinrich Böll Stiftung, p. 4, 14.

Borońska-Hryniewska K. (2016). Wpływ Brexitu na sytuację imigrantów ekonomicznych w Wielkiej Brytanii: implikacje dla Polski i polskich obywateli. Biuletyn PISM no. 24 (1374), p. 2.

Bundesamt für Migration und Flüchtlinge, (2016). Press release: Stärkung der Lehrkräfte in Integrationskursen Anhebung der Mindestvergütung für Honorarlehrkräfte auf 35 Euro.

https://www.bmi.bund.de/SharedDocs/pressemitteilungen/DE/2016/07/staerkung-der-lehrkraefte-in-integrationskursen.html (accessed: 17.06.2018).

Bundesamt für Migration und Flüchtlinge, (2018a). http://www.bamf.de/DE/Willkommen/DeutschLernen/Integrationskurse/InhaltAblauf/inhaltablauf-node.html (accessed: 15.06.2018)

Bundesamt für Migration und Flüchtlinge, (2018b). http://www.bamf.de/DE/Willkommen/DeutschLernen/Integrationskurse/SpezielleKursarten/Alphabetisierung/alphabetisierung-node.html (accessed: 15.06.2018). 